\title{
THE MODEL OF SOCIAL RELATIONS: STRATEGIC BEHAVIOUR, TRUST AND LOYALTY
}

\author{
Joseph Savirimuthu, Senior Lecturer in Law, Lancashire Law \\ School. *
}

\section{THE QUESTION}

The question:

"when can shareholders bring proceedings to enforce their or the company's rights?"1

may not be particularly original but it has important ramifications for both the individual and society. ${ }^{2}$ Two complementary paradigms have been relied upon at common law when determining questions of standing: (i) identifying the rights of the shareholders with reference to the separate legal personality of the business medium; or (ii) articulating policy justifications permitting departure from the principle of shareholder democracy. In both instances precedent dicates that access to the courts should be the exception rather than the rule. One could reasonably base this presumption against permitting the use of the judicial forum to address intra-corporate disputes, on the judiciary's unwillingness to become engulfed in matters raising issues where they have no relevant experience and the belief that internal governance structures were more than adequate to resolve the differences between the parties. ${ }^{3}$ This raises the obvious question, namely, what is the significance of the statutory oppression remedies and the recent proposals contained in the Law Commission Report which aims to increase transparency and accountability within business organisations by minimising procedural complexities in the current rules on standing? ${ }^{4}$ The specific goal of this article is to explore the critical questions of when and why the law seems particularly concerned with divergent interests in business organisations. Such questions invariably throw up a number of interesting ideas about the role of dispute mechanisms and the integrity of the internal governance framework in the business enterprise. At the heart of these ideas lie complex practical and doctrinal issues regarding the way power should be exercised,

* I am grateful to the anonymous reader for reading and commenting on an earlier version of this article. Responsibility for the final version is mine entirely.

1 Law Commission Consultation Paper No 142, Shareholder Remedies (London, Stationary Office, 1996) para 1.1.

2 B.L. Hay and K.E. Spier, "Settlement of Litigation" in P Newman (ed) The New Palgrave Dictionary of Economics and the Law, (1998) p 442.

3 B. Cheffins, Company Law: Theory, Structure and Operation (Oxford: Clarendon Press, 1997) pp 309-314.

4 Compare K. Wedderburn, "'Shareholders' Rights and the Rule in Foss v Harbottle", [1957] 16 Camb LJ 194 and R. Drury, 'The Relative Nature of Shareholder Rights to Enforce the Company Contract', [1986] 45 Camb LJ 219 with J. Lowry, "Reconstructing shareholder actions: a response to the Law Commission's Consultation Paper", (1997) 18 Company Lawyer 247 and P. Roberts (et $a l$ ), "Shareholder Remedies - Efficient Litigation and the Unfair Prejudice Remedy", [1999] JBL 38. 
made accountable and finally legitimated. ${ }^{5}$ This paper seeks to adopt a different approach to understanding the issues arising from the legal determination of questions of standing within the context of shareholder grievances in closely-held firms. I would like to shift the focus away from the traditional approaches to this subject which analysed questions of standing from the perspective of the relativity of the contractual rights under the common law and the curbs on opportunism under the statutory regime. ${ }^{6}$ Instead, I shall reorientate it on the central role of contract in the ordering of social relations in the company, the reasons for its prominence and its impact on questions of standing and more generally wealth creation. ${ }^{7}$ This should provide us with another source of ideas which can be utilised to enhance our understanding of the significance of the statutory developments and the recent proposals contained in the review on shareholder remedies. Before exploring these issues in greater detail, a snapshot of the historical antecedents leading to the creation of the regulatory framework of this business medium will provide us with an understanding of the underlying values and goals in the law's conception of the interactions between individual shareholders.

\section{THE ECONOMIC MODEL OF WEALTH CREATION: A HISTORICAL OVERVIEW}

A simple comparison between the regulatory framework governing partnerships and limited companies reveals significant differences in the legal ordering of relationships between individuals. In a partnership there is no distinction between management and its owners and in the event of any breakdown in relations, individuals can usually rely on their right to have their investment purchased. ${ }^{8}$ Such is not the case in respect of the company. Subject to any modifications in the constitution, the law gives particular prominence to the division of responsibilities and a heirarchy of power relations legitimated by the notion of shareholder democracy. History and economics give an insight into the reasons for this. ${ }^{9}$ Throughout the history of the business corporation one key challenge for the regulatory authority in the capitalist system has been to provide a framework which is both effective

5 See for example the essays in J. McCahery et al, (eds), Corporate Control and Accountability: Changing Structures and the Dynamics of Regulation (Oxford, Clarendon Press, 1993); J.E. Parkinson, Corporate Power and Responsibility: Issues in the Theory of Company Law (Oxford, Clarendon Press, 1994) pp 3-72.

6 See K. Wedderburn, "Shareholders' Rights and the Rule in Foss v Harbottle", [1957] Camb LJ 194 and [1958] Camb LJ 93; C.A. Riley "The values behind the Law Commission's Consultation Paper", (1997) 18 Company Lawyer 260; W.M. Rees "Shareholder Remedies", [1997] 5 ICCLR 155; S. Sheikh, "Shareholder Remedies", [1997] 2 ICCLR 47.

7 H. Collins, The Law of Contract, (3rd ed, 1997) pp 1-45, 89-127 and 374-376; S. Wheeler and J. Shaw, Contract Law: Cases, Materials and Commentary, (Oxford, Clarendon Press, 1996) Chapters 2 and 3.

8 Partnership Act 1890, section 32.

9 W.R. Cornish and G. de N. Clark, Law and Society in England 1750-1950 (London, Sweet \& Maxwell, 1989) pp 1-17, 79-92; more generally A.V. Dicey, Law and Public Opinion in England, (2nd ed, 1963); K. Renner, The Institutions of Private Law and their Social Functions (London, Routledge \& Kegan Paul Ltd,1949). 
and responsive to the dynamics of the market economy. That the ideology of the market should be deeply embedded in political and social spheres stems from its association with wealth creation. ${ }^{10}$ Advocates of this ideology emphasise the relationship between the pursuit of the utilitarian-liberal ideology with the advancement of an individual's self-interest on the one hand and that of the incorruptible nature of the market mechanism with the economic well-being of society on the other. The view posited is that rational individuals entering into consensual exchange transactions will lead to resources being efficiently allocated and utility maximised. It is no coincidence then that:

"the business enterprise enters the theory of the market economy, not as a social organization that takes an active role in managing its productive investments, but only as a 'productive function' that puts technical limits on how productive resources can be transformed into the products that consumers demand." 11

It is this simplicity and apparently content-neutral character of the economic model of wealth creation in a self-regulating market which perhaps explains its appeal and uncritical acceptance in post-feudal England. The market it was thought, except in cases of 'market failure', by virtue of its laws and arrangements could be relied upon to coordinate the production and distribution of wealth. ${ }^{12}$ In this period of experimentation, with no previous history of the workings of the market economy to draw upon, the elevation of the system of capitalism to a prominent role in society provoked no significant concerns from the political establishment of the day. ${ }^{13}$ Two observations can be made here. First, the way in which the market order and its arrangements for wealth creation serve to provide the necessary intellectual justification for limiting state intervention: interference in its 'natural order' and arrangements were viewed as being economically counterproductive and politically as well as socially, an unacceptable encroachment upon an individual's right to make voluntary choices. ${ }^{14}$ Second, the paradox of the instrumental role of market ideology: State patronage of the market economy was a necessary response to the constraining and limiting structures of feudal England's ability to attract

$10 \mathrm{~W}$. Lazonick, Business organization and the myth of the market economy (Cambridge Univ Press, First published 1991, paperback reprinted 1994) pp 5967.

11 Ibid, p 63.

12 Ibid, p 108; J.H. Farrar \& B. Hannigan, Farrar's Company Law, (4th ed, 1998) Chapters 14-17; J. Stanworth and C. Gray (ed), Bolton 20 years on (London, Paul Chapman Publishing, 1991) pp 1-3.

13 See F. Easterbrook and D. Fischel, The Economic Structure of Corporate Law (Cambridge, Harvard UP, 1991); cf J.A. Schumpeter, Capitalism, Socialism and Democracy (London, George, Allen \& Unwin, 1943) and K. Polanyi, Great Transformation (USA, Beacon Press, 1957).

14 W.R. Cornish and G. de N. Clark, Law and Society in England 1750-1950 (London, Sweet \& Maxwell, 1989) pp 246-266; see generally B.C. Hunt, The Development of the Business Corporation in England 1800-1867 (Cambridge, Harvard University Press, 1936). 
capital. ${ }^{15}$ The emergence of the system of capitalism led to a fundamental ordering of political and social structures:

". . . it means no less than the running of society as an adjunct to the market. Instead of economy being embedded in social relations, social relations are embedded in the economic system. . . [f]or once the economic system is organized in separate institutions, based on specific motives and conferring special status, society must be shaped in such a manner as to allow that system to function according to its own laws." 16

What is particularly striking about the dominance of the market economy ideology during the 18th and 19th centuries, was the way it circumscribed the role of the State and legal instruments. ${ }^{17}$ The idea of a self-regulating market and the image of voluntary consensual agreements was used to support the view of the company as nothing more than a simple profit maximising vehicle. ${ }^{18}$ Hence, the focus of the policy makers was to utilise statutory legal instruments to address pragmatic concerns like establishing the most efficient way of coordinating the various factors of production and facilitating finance structures. Running in tandem with this were more general complex doctrinal concerns relating to the public/private dichotomy of the business enterprise and the legitimacy of the rules defining ownership and accountability. The emerging statutory framework reflected a preoccupation with ensuring the company could properly function in the market environment. Incorporation and the other 'traits' of personhood were nothing more than facilities through which the limitations of capital could be overcome. ${ }^{19}$ For example, the concept of corporate personality served as an important device to simplify and organise the various underlying realities of accountability, responsibility and ownership. Equally important was the benefit of limited liability which was designed to ensure that the company had a workable financial base from which it could maximise its wealth creating potential. Insulating risk averse shareholders (that is, equity creditors) against personal liability was but a small concession. ${ }^{20}$ The priority given to the provision of a regulatory framework to facilitate the generation, maintenance and distribution of capital was designed to achieve clearly

15 K. Polanyi Great Transformation (USA, Beacon Press, 1957) Chapter 5 and R. Cotterrell, The Sociology of Law (London, Butterworths, 1992) pp 118-119.

16 Ibid. p 57.

17 For background information see A.B. DuBois, The English Business Company after the Bubble Act 1720-1800 (New York, Octagon Books, 1971) and A.V. Dicey, Law and Public Opinion in England, (2nd ed, 1963).

18 See B. Cheffins, Company Law: Theory, Structure and Operation (Oxford, Clarendon Press, 1996) pp 31-46.

19 P. Ireland, "The Triumph of the Company Legal Form, 1856-1914" in J. Adams (ed) Essays for Clive Schmitthoff (Abingdon, Professional Books Ltd, 1983) pp 29-58; B.C. Hunt, The Development of the Business Corporation in England 1800 1867 (Cambridge, Harvard University Press, 1936) pp 1-83; L.C.B. Gower, "A South Sea Heresy", (1952) 68 LQR 214.

20 B.C. Hunt, The Development of the Business Corporation in England 1800-1867 (Cambridge, Harvard University Press, 1936) pp 116-144; see generally O.E. Williamson, The Economic Institutions of Capitalism (New York, 1985). 
defined economic goals. $^{21}$ The statutory provisions coupled with uncompromising judicial supervision ensured that the funds were not dissipated through self-seeking conduct which would have undermined public confidence in the State's patronage of this business medium. ${ }^{22}$ In addition to this, the regulatory framework provided "individuals with facilities for realising their wishes, by conferring legal powers upon them to create, by certain specified procedures, and subject to certain conditions, structures of rights and duties within the coercive framework of the law." 23

Individuals, it should be noted, had the choice as to whether to opt into the regulatory framework and make relevant modifications in the model of social relations provided by the law. This was not an aspect with which business seemed to be concerned as trading relations were generally conducted in the shadow of the law. ${ }^{24}$ To the uninformed, however, the failure to recognise that different rules existed between a partnership and a company had important ramifications for the interaction between the participants. This was an aspect which was overseen by the judiciary. ${ }^{25}$

In summary, it can be observed that the lack of direct supervision by the State after providing a framework within which interactions were conducted could be attributed to a number of reasons: the relative lack of maturity of this particular form of business enterprise and the commercial environment, the perception of entitlements to rights and interests, the belief in the limited role of the State in the market economy and the conceptualisation of the 'company'as a production mechanism. ${ }^{26}$

\section{THE CONTRACTUAL MODEL OF SOCIAL RELATIONS}

The period between the 18th and 19th centuries can be seen as marking the transition of society from its reliance on status as a means of ordering social relations to that of contract. ${ }^{27}$ One probably needs no reminder to note that the appeal of the law of contract to the wealth maximising goal of the market economy runs deep in English jurisprudence. ${ }^{28}$ The idea of voluntary consensual contracting between private individuals is seen as being an efficient means of producing mutually beneficial outcomes and which in turn

21 A.B. DuBois, The English Business Company after the Bubble Act 1720-1800 (New York, Octagon Books, 1971) pp 346-434.

22 See Trevor v Whitworth (1887) 12 App Cas 409.

23 D. Sugarman and R. Rubin, "Introduction - Towards A New History of Law and Material Society" in G.R. Rubin and D. Sugarman (eds) Law Economy \& Society, Essays in the History of English Law 1750-1914 (Professional Books, 1984) pp 10-11.

24 Ibid.

25 See below.

26 A.B. DuBois, The English Business Company after the Bubble Act 1720-1800 (New York, Octagon Books, 1971) pp 302-307, 346-348.

27 R. Cotterrell, The Sociology of Law (London, Butterworths, 1992) pp 118-119 and M. Cohen, "The Basis of Contract", (1933) 44 Harv L Rev. 553, 562.

28 See W. Blackstone, Commentaries on the Law of England 4 Vols, (15th ed, 1809); P. Atiyah, The Rise and Fall of Freedom of Contract (Oxford, OUP, 1979); P. Hamburgher, "The Development of the Nineteenth Century Consensus Theory of Contract”, (1989) 7 Law \& Hist Rev 24. 
is seen as enhancing the welfare of society. ${ }^{29}$ That it is viewed in largely utilitarian terms stems from its underlying characteristics: the facilitation of pareto-superior outcomes in utility maximising transactions between rational individuals, enabling the transfer of ownership of goods and services and the affinity of its formal structures with notions of individual autonomy, minimal state intrusion and the market. ${ }^{30}$ The contractualisation of social relations is significant in two respects; first, it entrenches the device of contract and its underlying values and obligations to the governance of social relations and secondly, primacy is given to the obligations created therein over nonpecuniary obligations like legitimate expectations, loyalty and trust. ${ }^{31}$ The much heralded affinity between the model of social relations constructed by the law and the market also contains an important political message:

“. . . they provide a solution to a problem for loss of confidence in the institutionalized structures giving direction to people's lives. The preference for markets is symptomatic of a scepticism with respect to any claim to know best how social relations should be organized, what standards they should observe and perhaps a fear that any institutionalized power of control over social relations will be abused and employed to destroy individuality." 32

The interesting issue here is to examine the instrumental role of the contractual ordering of social relations in the company. The first point that one can make is that the perception of obligations between shareholders being consensual and voluntary is turned on its head by the imposition of a statutory contract which dictates relations within the company. ${ }^{33}$ Section 14 of the Companies Act 1985 provides that membership subjects all shareholders to a binding contract. The ordering of relations through this device is significant in a number of respects. ${ }^{34}$ First, the obligations and rights between the parties are determined by reference to the company's

29 See Jensen and Meckling, "Theory of the Firm: Managerial Behaviour: Agency Costs, and Ownership Structure", (1976) 3 J Fin Econ 305; H. Collins, The Law of Contract, 3rd ed (London, Butterworths, 1997) pp 3-10; F.S. McChesney "Legal Change and Small Business Law", (1997) 1 Journal of Small and Emerging Business Law 1 at 5 .

30 R Coase, "The Problem of Social Cost", (1960) 3 J Law \& Economics 1; Calabresi and Melamed, "Property Rules, Liability Rules, and Inalienability: One view of the Cathedral", (1972) 85 Harv L Rev 1089; but see V. Brudney, "Corporate Governance, Agency Costs and the Rhetoric of Contract", (1985) 85 Colum L Rev 1085, De Mott, "Beyond Metaphor: An Analysis of Fiduciary Obligation", [1988] Duke LJ 879 and V. Brudney, "Contract and Fiduciary Duty in Corporate Law", (1997) 38 Boston College L Rev 595.

31 H. Collins, The Law of Contract, (3rd ed, 1997) p 89. This does not however preclude the deployment of fiduciary principles. Such principles could be broadly construed as safeguarding the economic interests of the 'persona ficta'. Breaches of fiduciaries could only be enforced by the 'company' in general meeting.

32 H. Collins, The Law of Contract, (3rd ed, 1997) p 90.

33 Individuals incorporate with little understanding of the terms of the contract and the significance of the articles of association. The early jurisprudence of the contractual effect of the articles of association reflects a feature of the common law - providing solutions to problems as they accrued.

34 Ibid pp 102-104 
memorandum and articles of association but in itself do not give rise to legally enforceable remedies. The law to this end is preoccupied with giving effect to the 'bargain' deemed to be entrenched in the company's constitution and hence as a consequence attaches little importance to any 'legitimate expectations' that may have been created by virtue of the parties ongoing relationship. Second, the imposition of the contract device 'depersonalises' relationships within the business venture. For instance, the model of social relations defines individuals as 'director' or 'shareholder' and characterises their respective rights and obligations accordingly. This has the effect of rendering the personal circumstances, size of investments or expectations virtually superfluous to any determination of rights or remedies. For example, the 'share' entitles its owner only to 'a bundle of rights', but its precise scope and nature is left ambiguous. ${ }^{35}$ The interests of the shareholder are viewed primarily in quantifiable terms with little or no accommodation of expectations like trust, duty or loyalty. Amidst this ordering of social relations the 'persona ficta' and not the shareholder is treated as the primary beneficiary of many of the rights, duties and obligations. Finally, the contractualisation of social relations leads to a hierarchy of power relations supplemented by rules and structures which are elevated to a constitutional status. It is worth reminding ourselves of the extent of this 'distortive' effect on social relations by drawing a comparison with the ordering of relationships in a partnership. In this business medium even though the relationship is governed by contract it does not lead to the creation of a unilateral system of rule making or a hierarchy of power relations. ${ }^{36}$ All individuals are partners and subject to contrary provisions, have rights and obligations which are mutually enforceable and the social cohesion is provided by the overarching obligations of good faith, trust and loyalty. This is in clear contrast with the accompanying state of affairs if such individuals were to incorporate their business. For instance, shareholders in general meeting are vested with the responsibility of exercising stewardship over the moral hazard and principal-agency problems that emerge from the allocation of management functions to the board of directors. ${ }^{37}$ This model of social ordering is adhered to even though no distinction between ownership and management may exist. The restrictive interpretation of the statutory contract and the limited avenue for enforcing rights is usually justified on efficiency grounds, citing the economic consequences of multiple lawsuits, 'free-rider' problems, the avoidance of disruption of the business and the detrimental impact of litigation on relationships. ${ }^{38}$ DuBois affirms the principle of shareholder democracy on the grounds that:

35 P. Ireland, "Company Law and The Myth of the Shareholder Ownership" (1999) 62 MLR 32.

36 G. Morse, Partnership Law, (3rd ed, 1986) pp 108-142.

37 See Automatic Self-Cleansing Filter Syndicate Co Ltd v Cunninghame [1906] 2 Ch 34; Hickman v Kent [1915] 1 Ch 881; Quin \& Axtens Ltd v Salmon [1909] 1 Ch 311; Beattie v E \& F Beattie Ltd [1938] Ch 708; Y. Kotowitz, "Moral Hazard", in J. Eatwell, Milgate and P Newman, (eds) The New Palgrave: A Dictionary of Economics vol 3 (1987) pp 549-551; Boardman v Phipps [1967] 2 AC 46; E.J. Weinrib, "The Fiduciary Obligation", (1975) 24 Univ Toronto LR 1.

38 L.S. Sealy, "The Enforcement of Partnership Agreements, Articles of Association and Shareholder Agreements" in P. Finn (ed) Equity and Commercial Relationships (Sydney, Law Book Co, 1987) p 89; R. Drury, 'The Relative Nature 
“. . . rule by the majority was the essence of the organization. In charters, in articles of association, in acts of incorporation, there were to be found numerous provisions which sought to guarantee the advantages of speed and decision that majority control made possible." 39

It should be noted that in the general scheme of things the contractualisation of social relations does work - otherwise no one will wish to be a minority shareholder. ${ }^{40}$ This does not detract in any way from our highlighting the bias in the contractual model towards economic values and goals and its implications for the ordering of social relations particularly when individuals decide to act strategically.

Before proceeding to identify the reasons motivating decisions to act strategically, it is important to recognise the significance of traditional judicial perceptions of their role in the processing of disputes between shareholders. Judicial sympathies with the integrity of the contractual ordering of social relations is reaffirmed by the erection of procedural barriers to inhibit litigation. This is commonly known as the rule in Foss v Harbottle. ${ }^{41}$ The minority shareholders in this company were concerned about what they perceived as a clear abuse by its directors of their duties resulting from them making a profit on a sale of property to the company. The response of Wigram $\mathrm{V}-\mathrm{C}$ was clear and uncompromising. It was held that in respect of any improprieties or mismanagement within the company, individual shareholders were not legally recognised as beneficiaries entitled to redress on the basis of the privity doctrine. This, the court stressed, was consistent with the bargain reached under the statutory contract. Following from this, the rule states that only the 'company' through its proper constitutional body is entitled to either pursue relief through the courts or ratify the impropriety concerned. As the Court of Appeal in Prudential Assurance Co Ltd v Newman Industries (No2) noted “. . . [the] rule is not merely a tiresome procedural obstacle placed in the path of a shareholder by a legalistic judiciary. The rule is the consequence of the fact that a corporation is a separate legal entity. ..." 42 .

The exceptions to the presumption against legal intervention, in particular the 'fraud on the minority' exception, reflects judicial acknowledgment of the limits to the autonomy of the contractual model of social relations. A clear exposition of the limits to the private ordering of individual relations can be found in the judgment of Jenkins LJ in Edwards v Halliwell. ${ }^{43}$ In essence, judicial intervention was deemed to be justified in cases where it could be shown that the conduct of the directors / majority shareholders pointed to a

of a Shareholder's Right to Enforce the Company Contract', [1986] 45 Camb LJ 219.

39 A.B. DuBois, The English Business Company after the Bubble Act 1720-1800 (New York, Octagon Books, 1971) pp 302-303.

40 T. O'Neil, "Self-Interest and Concern for Others in the owner-managed firm: A Suggested Approach to Dissolution and Fiduciary Obligation in Close Corporations" [1992] 22 Seton Hall L Rev 646, 649.

412 Hare 461; also Mozley v Alston (1847) 1 Ph 790.

42 [1982] Ch 204, 223.

43 [1952] 2 All ER 1064, 1067. See also Prudential Asurance Co Ltd v Newman Industries (No2) [1982] Ch 204. 
clear departure from accepted social norms and values. ${ }^{44}$ For example, a shareholder could pursue a personal action if he could point to the infringement of a legally recognised personal right, as was the case in Pender $\mathrm{v}$ Lushington. ${ }^{45}$ Jessel MR in this case was of the view that a denial of a right to vote was an individual right which could not be encroached upon by the majority in the company. It should however be stressed that as the scope and nature of the rights which were enforceable under the statutory contract were narrowly defined, recourse to the courts through this avenue was illusory. ${ }^{46}$ In cases where there had been a breach of duty on the part of the directors, resulting in loss to the company's assets, it was made clear that with the exception of fraud, mere negligence in itself did not give rise to any personal remedy for the shareholder. ${ }^{47}$ Judicial intervention at best can be described as being selective; access to the courts seems broadly to be permitted if failure on the part of the 'company' to seek redress is viewed as being tantamount to a failure to exercise voting powers responsibly or where the benefits accruing to company officers is an equitable fraud on the company. ${ }^{48}$ Any suggestion that these interventions might provide the momentum for greater judicial activism was short circuited by the raising of additional formalist barriers like obtaining independent ratification and judicial approval in funding litigation costs. ${ }^{49}$ For example, in Smith v Croft (No 2) the mere fact of there being evidence of 'fraud' was regarded by the court as being insufficient to permit legal intervention. ${ }^{50}$ The view of Knox $\mathbf{J}$ was that:

"[u]ltimately the question which has to be answered in order to determine whether the rule in Foss v Harbottle applies to prevent a minority shareholder seeking relief as plaintiff for the benefit of the company is 'Is the plaintiff being improperly prevented from bringing these proceedings on behalf of the company?' If it is an expression of the corporate will of the company by an appropriate independent organ that is preventing the plaintiff from prosecuting the action he is not

44 See Cook v Deeks [1916] 1 AC 554; Daniels v Daniels [1978] Ch 406.

45 (1877) 6 Ch D 70.

46 Wood v Odessa Waterworks Co (1889) 42 Ch D 636, Pender v Lushington (1877) 6 Ch D 70; also see Prudential Assurance Co v Newman Industries Ltd (No2) [1982] 1 All ER 354; Stein v Blake and others (No2) [1998] 1 BCLC 573. However, in the ruling by the Court of Appeal in Barings plc (in admin) v Coopers \& Lybrand (a firm) [1997] 1 BCLC 427 it was observed that individuals could have a legally recognisable interest in relation to the diminution in the value of the shareholding if a duty of care was shown to be present.

47 Pavlides v Jensen [1956] 2 All ER 518

48 Daniels v Daniels [1978] Ch 406; Estmanco (Kilner House) v GLC [1982] 1 WLR 2.

49 See Wallersteiner v Moir (No2) [1955] QB 373; Smith v Croft (No2) [1998] Ch 114; L.S. Sealy, "Problems of Standing, Pleading and Proof in Corporate Litigation" in B. Pettet (ed) Company Law in Change CLP (London, Stevens, 1997); Prudential Assurance v Newman [1982] Ch 204; see A. Boyle, "Judicial Policy and the Derivative Action" in Developments in European Company Law Vol 1 Barry Rider and Mads Andenas (ed) (London: Kluwer, 1996) p111. See also the ruling in Barrett v Duckett [1995] 1 BCLC 73 which increases the threshold for reliance on the 'fraud on the minority' exception.

50 [1988] Ch 114 
improperly but properly prevented and so the answer to the question is "No'." 51

One might conclude from the two extracts cited above that the law is

. objective and neutral, not a matter of politics or preference, but a settled body of rules and principles, legitimated by tradition and routine observance, and applied impartially and fairly to all citizens." 52

It has already been shown however, that this is not necessarily the case given the close relationship between the regulatory framework and the functioning of the market. ${ }^{53}$ For instance, the formalist approach to the processing of disputes assumes that interactions exist in a purely rational construct. This could be construed as evidence of judicial perception of the market environment rather than litigation as being the appropriate mechanism for maintaining discipline and order. There is however one serious issue that has received little attention. The marginal role of both the State and the courts in the private ordering of individual affairs has traditionally been perceived as being necessary, so as not to undermine the arrangements of the market order. The problem with this view is that it treats the market environment as being capable of maintaining stable as well as rational conditions within the company. To this end the contractual model of social relations assumes an important instrumental role. Is it entirely accurate to say that this model with its underlying economic values and norms is responsible for the maintenance of stability amongst the individuals? This question can be approached in another way. What if it is shown that the emerging institutional role reflects an increasing awareness of the failure of this basic model to maintain the 'rational conditions'? What does this indicate in terms of the general policy and the modern role of legal instruments? It is these and related questions that the remainder of the paper seeks to address.

\section{INSTITUTIONALISM AND THE PROBLEM OF SOCIAL RELATIONS}

It will be apparent from the previous discussion that there is an inextricable link between the primacy given to contractual values and norms on the one hand and judicial perceptions of their role in processing disputes on the other. These seemingly logical and necessary rules contain:

“. . . two principal dangers which may be provoked by experimentation through contracts. In the first place, law of contract analyses and evaluates social relations from within its confines by reference to criteria which may lead to an undesirable distortion of the meaning of the social relation involved. Secondly, the seductive attraction of avoidance of explicit distributive decisons by delegating outcomes to the

51 Ibid 185

52 H. Collins, The Law of Contract (3rd ed, 1997) p 7; I.R. Macneil, The New Social Contract,An Inquiry into Modern Contractual Relations (Yale Univ Press, 1980) pp 93-94.

53 M.J. Whincop, “Overcoming Corporate Law: Instrumentalism, Pragmatism and the Separate Legal Entity Concept" (1997) 15 Comp and Securities LJ 411, 411413. 
market mechanism can pose a threat to important principles of distributive justice." ${ }^{54}$

One archetypal complaint in a closely-held firm - denial of legitimate expectations - can be used to illuminate these concerns. ${ }^{55}$ A business run by two individuals is incorporated. Both parties become directors and shareholders in the company. It is later agreed that a friend of one of the directors should be brought into the business. This individual is appointed as director and acquires shares in the company. The founders of the business have a falling out. The two friends exercise their rights under the Companies Act 1985, section 303, removing the co-founder as director. The operation of the principle of shareholder democracy and the rule in Foss v Harbottle means that the issues arising here will be determined by a literalist construction of the 'bargain'.

This broadbrush approach to social relations under the contract model attaches little significance to legitimate expectations or the fact that when interests within businesses conflict parties should be expected to reach a compromise. The culture of profit maximisation seems ill-equipped to accommodate the notion that the company is also a social organisation. If one accepts that contract as a social ordering mechanism suffers from this and other failings we need to assess the particular significance of the modern role of legal instruments, notably section 459 of the Companies Act 1985 and to a lesser extent section 122(1)(g) of the Insolvency Act 1986 in this context. In contrast to the common law's stance on upholding the primacy of the governance model of social relations, these provisions at first blush can be viewed as providing an important avenue for shareholders to subject the decision-making process within the model of social relations to judicial scrutiny. ${ }^{56}$ Minority shareholders now have ready access to the courts in situations where divergences in interests lead to majority shareholders using their voting powers to either enforce a literalist construction of the statutory contract or to depart from previous understandings. The importance of the institutional dimension to the private ordering of individual affairs lies in the way it questions traditional conceptions of the 'company', 'interests' and the approach to wealth creation. ${ }^{57}$ In Re a Company (No 00477 of 1986) Hoffmann $J$ (as he then was) stressed that the unfair prejudice provision enabled the court to take into account wider equitable considerations when scrutinising relationships within the company. ${ }^{58}$ In Re Saul D Harrison and Sons plc it was noted that:

“. . . [conduct] can also be unfair without being unlawful. In a commercial context, this may at first seem surprising. How can it be unfair to act in accordance with what the parties have

54 H. Collins, The Law of Contract (3rd ed, 1997) p 102.

55 E. Boros, Minority Shareholders' Remedies (Oxford, Clarendon Press, 1995) pp 58.

56 See the Cohen Report Cmd 6659 which resulted in the passing of section 210 Companies Act 1948.

57 Scottish Co-operative Wholesale Society Ltd v Meyer [1958] 3 All ER 66; Re HR Harmer [1959] 1 WLR 62. Also E. Boros, Minority Shareholder Remedies (Oxford: Clarendon Press, 1995) pp135-155; see Re Saul D Harrison [1995] 1 BCLC 14 and Re Elgindata Ltd [1991] BCLC 959.

582 BCC 99; see also Ebrahimi v Westbourne Galleries Ltd [1973] AC 360. 


\section{Northern Ireland Legal Quarterly [Vol. 51, No. 2]}

agreed? As a general rule, it is not. But there are cases in which the letter of the articles does not fully reflect the understandings upon which the shareholders are associated. . . Thus the personal relationship between a shareholder and those who control the company may entitle him to say that it would in certain circumstances be unfair for them to exercise a power conferred by the articles upon the board or the company in general meeting. . . [a legitimate expectation] often arises out of a fundamental understanding between the shareholders which formed the basis of their association but was not put into contract form." 59

One detects from this passage not only a fundamental shift away from the previously uncritical attitude towards the primacy of contract ideology but a heightened awareness of the organisational dimension of the 'family' or 'lifestyle' company and the value of social norms in the wealth creation process. ${ }^{60}$ It is important at this juncture to make clear for present purposes what we mean when we say a breach of 'trust' or a departure from 'social norms' gives rise to a remedy under the statutory regime. For example, a dictionary definition of 'trust' is "[f]aith, or confidence in the loyalty, strength, veracity. . . of a person." 61

In company law however, it has been made clear that not every reliance, divergence in interest, allegations of unfairness or prejudicial conduct will give rise to a legal remedy. ${ }^{62}$ As the Court of Appeal recently indicated:

"In deciding what is fair or unfair for the purposes of s.459, it is important to have in mind that fairness is being used in the context of a commercial relationship. The articles of association are just what their name implies: the contractual terms which govern the relationships of the shareholder with the company and each other. Since keeping promises and honouring agreements is probably the most important element of commercial fairness the starting point in any case under s.459 will be to ask whether the conduct of which the shareholder complains was in accordance with the articles of association. A finding that conduct was not in accordance with the articles does not necessarily mean that it was unfair still less that the court will exercise its discretion to grant relief." 63

This is an important judicial acknowledgment that divergences of interests invariably arise in business relations and that the law should not be utilised to

59 [1994] BCC 475, 489-90.

60 See Re Postgate \& Denby (Agencies) Ltd [1987] BCLC 8; Re Cumuna Ltd [1986] BCLC 430; Re a Company [1986] BCLC 376.

61 The New Shorter Oxford English Dictionary Volume 2, L Brown (ed) (Oxford, Clarendon Press, 1993) p 3411.

62 Re a Company [1986] BCLC 362; Re London School of Electronics [1985] 3 WLR 474; E. Boros, Minority Shareholder Remedies (Oxford: Clarendon Press, 1995) pp 128-152.

63 Re Saul D Harrison [1994] BCC 475, 488-489. 
reduce business relations to legal propositions. ${ }^{64}$ This much is evident from the observations of the House of Lords in Ebrahimi v Westbourne Galleries. ${ }^{65}$ The Law Lords in subjecting the exercise of legal rights to equitable considerations stressed that this could only be justified where the act or omission was tantamount to a departure from certain fundamental understandings contrary to good faith. ${ }^{66}$ More recently, Lord Hoffmann noted in $\operatorname{Re}$ a Company that the mere fact that trust and confidence between the parties had broken down did not invariably give rise to a legal remedy. ${ }^{67}$ Individuals in business must accept the risk that at times divergences of interests may place them at a disadvantage. Where the petitioner is successful, in contrast to the position at common law, the court has extensive powers which include the right to institute a derivative suit, order a 'buy-out' or regulate the affairs of the company. ${ }^{68}$

It will be observed that the proactive institutional role has led to a shift in focus away from the notion of contract as a primary governance model. This is significant in a number of respects - first, its recognition that the individual shareholder is distinct from the company and capable of having expectations and interests which extend beyond the economic rights associated with share ownership. ${ }^{69}$ Second, it permits claims by individual shareholders even though technically the company has a similar entitlement. ${ }^{70}$ Third, it provides a solution to the adverse consequences accompanying the imposition of a hierarchy of power relations in the company. ${ }^{71}$ Individual shareholders in closely-held firms can obtain a remedy based on an objective standard of fairness and hence not dependent on proof of mala fides. ${ }^{72}$ For completeness, it should be pointed out that the limitations of the model of social relations is not particularly problematic in the case of minority shareholders in companies with public listings. Values like trust and loyalty seem not to fit in readily in an environment where there is an automatic exit remedy and shareholdings are generally viewed as investment opportunities. This much seems to be implied in the observation by Jonathan Parker $\mathrm{J}$ in Re Astec (BSR) plc:

“. . . the concept of 'legitimate expectations'. . . can have no place in the context of public listed companies. Moreover, its introduction in that context would, as it seems to me, in all probability prove to be a recipe for chaos. If the market in a

64 D. Sugarman and R. Rubin, "Introduction - Towards A New History of Law and Material Society" in G.R. Rubin and D. Sugarman (eds) Law Economy \& Society, Essays in the History of English Law 1750-1914 (Professional Books, 1984).

65 [1973] AC 360; B. Rider, "Partnership Law and the Impact on Domestic Companies" [1979] CLJ 148

66 [1973] AC 360, 379.

67 1999] 2 All ER 961, 973.

68 See the remedies available under Company Act 1985, section 461; Re Postgate \& Denby (Agencies) Ltd [1987] BCLC 8; Re London School of Electronics [1985] 3 WLR 474.

69 Re a Company No 002567 of 1982 [1983] 1 WLR 927.

70 See Prudential Assurance Co Ltd v Newman Industries Ltd (No2) [1982] 1 All ER 354.

71 Re a Company [1986] BCLC 362.

72 Re R.A. Noble \& Sons (Clothing) Ltd [1983] BCLC 273. 
company's shares is to have any credibility, members of the public dealing in that market must it seems to be entitled to proceed on the footing that the constitution of the company is as appears in the company's public documents, unaffected by any extraneous equitable considerations and constraints." 73

\section{THE LAW COMMISSION REVIEW: A BRIEF COMMENT}

Any consideration of the model of social relations will not be complete without some reference to the Law Commission review with a view to highlighting the broader context within which it operates and its implications for approaches to wealth creation. ${ }^{74}$ An appreciation of this important development is necessary for three reasons, first: it draws our attention to the complex commercial environment within which regulations operate; second, to the increasing role of the State and finally, it reminds us that the increasing recourse to statutory legal instruments culminating in the recent review of 'Shareholder Remedies' is not the result of chance or coincidence. A number of factors can be relied upon to support the above assertions. First, the willingness of the judiciary to make the unfair prejudice remedy effective has had adverse implications. Disputes involving minority shareholders invariably lead to a thorough investigation of the history of the business relationship including the purpose of the venture and the conduct of the parties. This has a clearly detrimental effect on the business for obvious reasons. ${ }^{75}$ As a consequence parties have had to take into account the financial and economic consequences of instituting or defending legal proceedings. In Re Elgindata the order sought was a purchase of shares whose orginal value was $£ 40,000$. The proceedings went on for 43 days giving rise to costs of $£ 320,000$ and an order to purchase the shares at $£ 24,600$ was made..$^{76}$ The cost implications to individuals must also take into account the increasing burdens on the resources of the legal system. Second, there is also the wider commercial environment to consider. Increased reliance on public funds by institutional investors when investing in listed companies has raised another spectre - public scandals. ${ }^{77}$ Institutional pension and insurance fundholders now own close to $50 \%$ of the equity, in companies listed on the stock exchange. It has not escaped the reformers notice of the unsuitability of the unfair prejudice provisions and the problems in applying for a Wallersteiner order where the petitioner was an institutional shareholder. ${ }^{78}$ Third, the reform agenda owes its impetus to the publication

73 (1999) BCC 59, 87; see also Re Blue Arrow plc (1987) 3 BCC 618, 623 per Vinelott J, Leeds United Holdings plc [1997] BCC 137. See for example the valuable role of derivative actions in this respect: A Boyle, 'Judicial Policy and the Derivative Action' in Developments in European Company Law Vol 1 Barry Rider and Mads Andenas (eds) (Kluwer, 1996) 111. Also for a comparative perspective see: GP Stapledon 'Use of the Oppression Provision in Listed Companies in Australia and the United Kingdom', (1993) 67 Aust LJ 575.

74 Law Commission Consultation Paper No 142, Shareholder Remedies (London: HMSO, 1996).

75 Re Elgindata Ltd [1991] BCLC 959.

76 See Re Macro (Ipswich) Ltd [1994] 2 BCLC 354.

77 See however Re Astec (BSR) plc [1998] 2 BCLC 556.

78 D. Faber, "Reform of Shareholder Remedies" in Developments in European Company Law Vol 1 Barry Rider and Mads Andenas (eds) (Kluwer, 1996) p 119, 
of the Report on Access to Justice. ${ }^{79}$ Lord Woolf's proposals which have been extended to the field of company law could be viewed as the "visible hand' designed to minimise the strains on the public purse as well as improving access to justice. ${ }^{80}$ The significant point here is that in answering the question regarding standing, we can see the way the underlying values and goals of the market mechanism have permeated discussions on the function and role of 'private' and 'public' law in the civil justice system. ${ }^{81}$ As mentioned previously, shareholders' decisions to litigate not only impose costs on private individuals and the company but on society in terms of the costs of funding the legal system. ${ }^{82}$ Fourth, there is also a 'political' dimension in the move towards greater 'institutional' involvement in the private ordering of individual relations. ${ }^{83}$ The UK's membership in the European Union, for example, has seen greater moves towards harmonisation to facilitate the functioning of the single market. ${ }^{84}$ The Labour government has shown a commitment to providing a regulatory framework ". . . which is up-to-date, competitive and designed for the next century, a framework which facilitates enterprise and promotes transparency and fair dealing." 85

at 123; see A. Boyle, "Judicial Policy and the Derivative Action" in Developments in European Company Law Vol 1 Barry Rider and Mads Andenas (eds) (Kluwer, 1996) p 111, at 117.

79 Lord Woolf, Access to Justice, Final Report to the Lord Chancellor on the Civil Justice System in England and Wales (London, HMSO, 1996).

80 See trenchant criticism of Lord Woolf's proposals by M. Zander, "Access to Justice - Towards the 21st Century" in Law, Society, and Economy R. Rawlings (ed) (Oxford, Clarendon Press, 1997) 339. General discussion of these proposals can be found in A. Zuckerman and R. Cranston (eds) Reform of Civil Procedure in (Oxford: Clarendon 1995); P Fenn (et al) "Long-term Contracts in the Market for Health Care" in Contract and Economic Organisation, D. Campbell and P. Vincent-Jones (eds) (Dartmouth, 1996) 143. Law Commission Consultation Paper No 142, Shareholder Remedies (London: The Stationery Office, 1996); J. Eaglesham and J. Mason, "Legal system poised for 'big bang' overhaul from today", Financial Times April 26 1999, 10; J.A. Schumpeter, Capitalism, Socialism and Democracy (London, George, Allen \& Unwin, 1943) p 157.

81 See for example the collection of papers in P. Birks (ed), Wrongs and Remedies in the Twenty-First Century (Oxford, Clarendon Press, 1996).

82 N. Rickman, "The Economics of Cost-shifting Rules" in A. Zuckerman and R. Cranston, Reform of Civil Procedure (Oxford, Clarendon, 1995) p 327.

83 J. Gray, False Dawn (London, Granta Publications, 1998); W. Hutton, The State We're In (London, Vintage 1996); G. Soros, The Crisis of Global Capitalism (London, Little, Brown and Co 1998).

84 Buxbaum and Hopt, Legal Harmonisation and the Business Enterprise (European Univ Institute, 1988); F. Wooldridge, Company Law in the UK and the EC (London, Athlone Press, 1991); D. Wyatt (et al) European Community Law (London: Sweet \& Maxwell 1993); DTI, Business In Europe, The Single Market, Company Law Harmonisation (London: 1993). See also J. Kelly, 'Brussels accounting plans worry top companies' Financial Times 20/21 Feb 1999 at p6.

85 DTI, Modern Company Law For a Competitive Economy, (London, HMSO, 1998); Board of Trade, Report of the Company Law Committee (London, HMSO, Cmnd 1749); Report of the Committee of Inquiry on Small Firms: Small Firms (London, HMSO, Cmnd 4811, 1971); J. Stanworth and C. Gray (eds), Bolton 20 years on (London, Paul Chapman Publishing, 1991); J. Martinson, "Review of company law revives 'stakeholder' issue", Financial Times February 251999 1; J. Kelly and J. Martinson, "Epic act to pull company law out of Victorian era", 
The result of the review will see the rule in Foss v Harbottle being abrogated and in its place a new statutory derivative action, the present legal burden in petitions under section 459 being reversed and greater emphasis being placed on active case management and encouraging parties to utilise 'self-help' remedies. A survey of the existing literature shows that the response to the proposals has been far from favourable. ${ }^{86}$ Criticisms have already been directed towards the Commission's failure to accurately 'conceptualise' the nature of the problems, its broadbrush approach to intra-corporate grievances, the surprising omission of developments in jurisidictions within the European Union and the surprising segregation of the enforcement machinery and directors' duties. It is beyond the scope of this article to address the issues arising therefrom. Given the nature of the proposed reforms, it is worth exploring one aspect of the emerging role of legal instruments and the recent developments in the model of social relations.

\section{TRUST, DUTY AND LOYALTY AS 'CAPITAL'}

The theory of economic modelling and its influence in the basic model of social relations constructed by the law makes two fundamental assumptions: first, that rational behaviour is solely concerned with the productive/profit maximising goal of the company and second, the central role of the contractual model in maintaining 'rational conditions' within the company. ${ }^{87}$ Such assumptions reflect the ". . . failure. . . in the new institutional economics to recognize the importance of concrete personal relations and networks of relations. . . in generating trust, in establishing expectations, and in creating and enforcing norms." 88 This illustrates a tendency to treat such values and norms as being nothing more than "a sort of ever-ready lubricant

Financial Times 26 February 199; The Report of the Committee on the Financial Aspects of Corporate Governance (London, 1992); Director's Remuneration: The Report of a Study Group chaired by Sir Richard Greenbury (London, 1992); The Law Society, Memorandum by the Society's Standing Committee on Company Law: A New Form of Incorporation for Small Firms (The Law Society, No 79, 1981); Forum of Private Business, A Report into Business Legal Structures (London, 1991) DTI, Company Law Review: The Law Applicable to Private Companies (London: DTI, URN 94/529, 1994).

86 D. Sugarman, "Reconceptualising company law: reflections on the Law Commission's consultation paper on shareholder remedies: Part 1" (1997) 18 Company Lawyer 226; "Part 2" (1997) 18 Company Lawyer 274; J. Lowry "Reconstructing shareholder actions: a response to the Law Commission's Consultation Paper" (1997) 18 Company Lawyer 247; A.J. Boyle "The new derivative action" (1997) 18 Company Lawyer 256; C.A.Riley "The values behind the Law Commission's consultation paper" (1997) 18 Company Lawyer 260; L.J. Moran "Missing links and missed opportunities" (1997) 18 264; W.M. Rees "Shareholder Remedies" [1997] 5 ICCLR 155; S. Sheikh, "Shareholder Remedies" [1997] 2 ICCLR 47; P. Roberts (et al), "Shareholder Remedies - Efficient Litigation and the Unfair Prejudice Remedy" [1999] JBL 38; cf D. Capper, "Keeping Woolf From the Door - The Reform of Civil Procedure in Northern Ireland" (1999) 50 NILQ 434.

87 B. Chapman, "Trust, Economic Rationality, and the Corporate Fiduciary Obligation" (1993) 43 Univ Toronto LJ 547,579.

88 J. Coleman, Foundations of Social Theory, (Cambridge, Harvard UP, 1990) p 302. 
that permits voluntary participation in production and exchange." 89 However focussing on the company as a 'social organisation' enables us to expose the limitations of these assumptions. For instance, it is accepted that relationships between individuals in companies are conducted amicably. If conflicts of interests emerge, it is reasonable to assume that 'rational' individuals will not be preoccupied with profit maximising goals. Rather, every effort will be made to reach a consensus or compromise through recourse to established social norms and values. Interestingly, where such norms and values cease to have any stabilising influence, it is because of the fact that the relationship has already run its course. In such instances, majority shareholders resort to the contractual model of social ordering. ${ }^{90}$ Viewing business as a game will help illuminate the points made above. ${ }^{91}$ Shareholders in closely-held firms can be seen as players engaged in strategic decision-making in an environment of interdependence. Each individual during the course of the business relationship regularly evaluates his goals, the conduct and reactions of the other parties and the strategies which maximises his payoff. ${ }^{92}$ The decisions each individual makes will be influenced by his perception and understanding of what the other participants are likely to decide and the options open to them. As each player is 'rational' he will opt for those strategies which offer him the best payoff. ${ }^{93}$ Where relations between the players are harmonious, the strategic interactions are unlikely to give rise to coordination problems resulting in litigation. The 'common' or 'group interest' it could be assumed will be maintained, so long as the players perceive norms and values like cooperation, trust and loyalty as being crucial to the continuance of the business relationship. This perhaps explains in part, the valuable role of social norms and values in addressing conflict situations in the business relationship. It is to be noted, however, that the ordering of social relations in these 'rational conditions' is being achieved by non-economic values and processes rather than through the contractual model of social relations. ${ }^{94}$ It is a trite point that social relations are never ceteris paribus. Competing goals, expectations or changed circumstances in situations where there has been an irretrievable breakdown in relations or where the pursuit of self-interest is viewed as being more important than the common interest, results in the

89 P. Dasgupta, "Trust as a Commodity" in Trust: Making and Breaking Cooperative Relations Diego Gambetta (ed) (Basil Blackwell, 1990) p 49.

90 B. Cheffins, Company Law: Theory, Structure, and Operation (Oxford, Clarendon Press, 1997) Ch 6; J. McMillan, Games, Strategies and Managers (Oxford, 1992) p 25; A. Katz, "The Strategic Structure of Offer and Acceptance: Game Theory and the Law of Contract Formation", (1990) 89 Michigan LR 216.

91 J. McMillan, Games, Strategies and Managers (Oxford, 1992) pp 3-6.

92 Ibid, pp 25-27; R. Cooter, "The Cost of Coase", (1982) 11 Journal of Legal Studies 1, 1-29.

93 O. Young, 'Introduction', Oran R. Young (ed) Bargaining, Formal Theories of Negotiation (Chicago, Univ of Illinois Press, 1975) 22-24; J. McMillan, Games, Strategies and Managers (Oxford, 1992) pp 3-6.

94 I. MacNeil, "Economic Analysis of Contractual Relations: Its Shortfalls and the Need for a 'Rich Classificatory Apparatus' ", (1981) NW Univ L Rev 75, 1047 1048. 
parties reverting to the contractual model..$^{95}$ The primacy accorded to majority rule creates a zero-sum game whereby one party always wins and the other loses. As Collins observes, where there has been a divergence of interest, the contractual model assumes strategic proportions as it:

"permits each group to pursue its interests without any concern for the other parties who are bound to the firm. Once the articles of association become regarded as simply another contract, this time between shareholders, then this contractual framework destroys any sense that the corporate entity comprises an organization, which has to balance and protect the interests of various constituencies or members." 96

There are two ways of viewing the limited intervention by the State in the provision of minority oppression remedies. ${ }^{97}$ One is that the institution is being relied upon to ensure as far as possible that 'rational conditions' are maintained; the other, as a remedy available in respect of departures from accepted social norms and values. That the model of social relations suffers from a 'trust deficit' has to some extent been understood by shareholders in closely-held firms, in view of the increasing recourse to legal advice and shareholder agreements. ${ }^{98}$ The emergence of statutory legal instruments reflects an important role being assumed by the law. It is indisputable that legal instruments which increase accountability and transparency in the decision-making process in companies, are capable of creating conditions where norms and values like 'trust', 'duty' and 'loyalty' can thrive. What significance can we attach to these institutional developments in the wider policy of wealth creation? It will be observed that under the conventional approach to wealth creation, capital contributions were seen as its mainstay. A symbiotic relationship seems to have been accepted almost uncritically between the orthodox notion of capital, with its emphasis on brick, motor, plant, buildings and money and the conceptualisation of the 'company' and the roles of legal instruments and structures in the ordering and governance of social relations. ${ }^{99}$ Ingrained in this process of wealth creation is a closed system of thought involving ". . . mindsets. . . stuck in an old model, in

95 F. Fukuyama, Trust: The Social Virtues and the Creation of Prosperity (London, Hamish Hamilton, 1995) pp 3-4; B Chapman, 'Trust, Economic Rationality, and the Corporate Fiduciary Obligation', (1993) 43 Univ Toronto LJ 547, 550

96 H. Collins, The Law of Contract (3rd ed, 1997) p 78.

97 In particular Companies Act 1985, section 459.

98 Evidence that shareholders in companies are insuring themselves against strategic behaviour are anecdotal but such a course has received judicial imprimatur and its appropriateness acknowledged by the Law Commission. See for instance Cumbrian Newspapers Group Ltd v Cumberland \& Westmorland Herald Newspaper \& Printing Co [1986] 3 WLR 26; G. Stedman and J. Jones, Shareholder Agreements, (2nd ed, 1990); Russell v Northern Bank Development Bank Corp [1992] 1 WLR 588.

99 O-Kahn Freund "Some Reflections on Company Law Reform", (1944) MLR 54,60; F. Fukuyama, Trust: The Social Virtues and the Creation of Prosperity (London, Hamish Hamilton, 1995) pp 3-4; K.A. Chrystal and R.G. Lipsey, Economics for Business and Management (Oxford, 1996) pp 123; J.H. Farrar \& B. Hannigan, Farrar's Company Law (4th ed, 1998) Ch 14-17. 
which shareholders put up risk capital that is used to build the factory. . . and the job of management is to maximize profits for shareholders." 100

It is this disembodied approach to wealth creation (for example, viewing capital as a thing) which is perpetuated by the uncompromising characteristics of majority rule, a bias towards the legal fiction of the company and the tacit acceptance of an adversarial approach to wealth creation. The evolution of company law and the attitude of its institutions towards managing severe divergences should not be restricted to its symbolic value. These developments can be seen as a deliberate move towards a more consensus oriented approach to wealth creation. ${ }^{101}$ In doing so, the spotlight is trained firmly on the value of social relations in the wealth creation process. Since economic relations between shareholders in closely-held firms are entrenched in relationships, it may seem foolish not to integrate this into the wealth creating process. It should be said that the idea of a set of social relations as generating value or 'capital' is not particularly controversial. ${ }^{102}$ There is less agreement on whether and to what extent legal instruments can be utilised to this end. ${ }^{103}$ We are concerned here with values and norms like 'trust', 'duty' and 'loyalty' which enable parties to maximise the potential of their existing resources. ${ }^{104}$ Unlike physical and human capital which are more tangible than the notion of social capital, this is not a basis for precluding the latter's capabilities in facilitating productive relationships, strengthening commitments in times of conflict and providing the impetus to attain particular ends or goals. ${ }^{105}$ It is usual when discussing the value of 'trust' in the commercial environment to refer to a book written by Francis Fukuyama - Trust: The Social Virtues and the Creation of Prosperity. ${ }^{106}$ In his comparison of the varied performances between economies, he observes the correspondence between high economic attaintment and high levels of trust. ${ }^{107}$ Economies in societies, he argues, where there is a trust deficit tend not to perform well. ${ }^{108}$ One may perhaps not dissent from the underlying ideas but it does however require some obvious qualifications. For example, equating economic prosperity with a country's social capital is to take an over simplistic view of economic success or

100 M. Blair, Ownership and Control (Washington, Brookings Institution) p 324.

101 R. Hardin, "Trust" in The New Palgrave Dictionary of Economics and the Law, (ed P Newman) (1998) p 623.

102 J. Charkham, Keeping Good Company: A Study of Corporate Governance in Five Countries (Oxford: Clarendon Press) Chapters 1-3; T. Sheridan and N. Kendall, Corporate Governance: An Action Plan for Profitability and Business Success (London: Pitman, 1992) Chapters 4-6 and 8.

103 B. Cheffin, 'Trust, Loyalty and Cooperation in the Business Community: Is Regulation Required?' in B. Rider (ed), et al The Realm of Company Law (Oxford: Clarendon Press,) p 53.

104 Ibid pp 53, 65-66, 70-78.

105 J. Coleman, Foundations of Social Theory, (Cambridge, Harvard UP, 1990) pp 300-321.

106 (London: Hamish Hamilton, 1995).

107 Trust: The Social Virtues and the Creation of Prosperity (London: Hamish Hamilton, 1995)

108 Ibid p 4; R. Hardin, "Trust" in The New Palgrave Dictionary of Economics and the Law, (ed P Newman) (1998) p 623. 
underperformance. Comparisons between high-trust societies like Japan and one which has since ceased to possess such reserves like America, illustrate the dangers of adopting the thesis uncritically. ${ }^{109}$ Another example can be seen in the world-wide financial crisis of 1997. This serves as a reminder of the chaos that can be caused by the absence of real constraints on the mobility of capital in the modern global market. ${ }^{110}$ The problems which originated in Thailand in July of that year rapidly spread across the globe dampening the economic prospects of the 'Tiger Economies', causing meltdown in Russia and the depreciation of the currencies in Latin America. Finally, economic prosperity in the age of technology depends on the ability of a business to gain a competitive advantage in the marketplace. It is generally recognised that success or failure of an enterprise cannot be confined to using social capital as a yardstick; much will depend on the entrepreneur's ability to equip the business with organisational structures and processes which are both innovative as well as responsive to the pace and complexity of this commercial environment. Failing or underperforming economies / businesses in a number of instances have too often exhibited an ignorance of the evolutionary nature of capitalism and are unable to maximise the economic potential of the 'technological revolution' ${ }^{111}$ Despite these reservations the thesis does contain an important message - it emphasises the value of social capital. James Coleman argues that the various elements which broadly constitute social capital - trust, duty and loyalty - enable it to perform an important function. ${ }^{112}$ Where such elements are deemed to exist in abundance, individuals will be able to utilise these elements as resources to maximise their interests. It has already been shown in the discussion employing game strategy, how the absence of norms and values like 'trust' and 'loyalty' can undermine the efficacy of relations and the wealth creating potential of the commercial venture. ${ }^{113}$ As Fukuyama observes, a model which integrates social capital within the economic framework of the business enterprise will be more likely to facilitate productive relationships which have a "large and measurable economic value." 114

It is in this respect that the statutory oppression remedies, the introduction of rebuttable presumptions in specified situations and the availability of a statutory derivative action can be seen as an attempt to combine statutory instruments with the model of social relations to enable the realisation of the inherent potential of social resources. The legal instruments and proposed reforms attempt to minimise the deficiencies embedded in the contractual

109 F. Fukuyama, Trust: The Social Virtues and the Creation of Prosperity (London, Hamish Hamilton, 1995) pp 29-30, 277-281, 310-311.

110 G. Soros, The Crisis of Global Capitalism (London, Little, Brown and Co 1998).

111 J. Gray, False Dawn (London: Granta Publications, 1998); W Hutton, The State We're In (London: Vintage 1996); G. Soros, The Crisis of Global Capitalism (London: Little, Brown and Co 1998)

112 J. Coleman, Foundations of Social Theory, (Cambridge, Harvard UP, 1990) pp 301-306.

113 B. Cheffin, 'Trust, Loyalty and Cooperation in the Business Community: Is Regulation Required?' in B. Rider (ed), et al, The Realm of Company Law (Oxford: Clarendon Press) pp 53, 65-66, 70-78

114 F. Fukuyama, Trust: The Social Virtues and the Creation of Prosperity (London: Hamish Hamilton, 1995) p 10. 
model of social relations by increasing the likelihood of convergences in interests, as well creating the conditions which reduce occasions for engaging in strategic or opportunistic behaviour. ${ }^{115}$

\section{CONCLUSION}

Economic activity is founded on the notion that rational individuals enter into relations with a view to gaining from the co-operative venture. ${ }^{116} \mathrm{By}$ and large relationships within companies are undertaken without recourse to the law. ${ }^{117}$ In view of this, one may be tempted to suggest that:

“. . . business functions best when those engaging in commercial activity share a co-operative ethos and have a strong sense of trust and loyalty. . . various disadvantages of regulation indicate that it is undesirable to have obligations to act in a trustworthy, loyal and co-operative manner imposed by legislators or judges. Instead, to the extent that people rely on trust and related concepts when they carry on commercial activity, this should occur because that is how they believe they should behave, not because someone has told them to do so." 118

Whilst there is some merit in this view, it should be remembered that until the intervention of statute, company law was preoccupied with the market conception of the 'company'; the deference to contractual ideology and the assumption of rational behaviour overlooked a fundamental tenet of the human condition, namely that:

"human agents who populate the economic institutions of capitalism are lacking in compassion."119

When constructing the model of social relations, the legislators and judges seem to have either underestimated individuals' incentives to act responsibly or the market's capacity to discharge the function of distributive justice. ${ }^{120}$ The irony, as the law continues to evolve in this regard, is that:

". . . the private and highly localized virtues of loyalty and trust within an institution like the corporation, at least as much as the unconstrained pursuit of self-interest through contracts, can

115 Bruce L Hay and Kathyrn E Spier, 'Settlement of Litigation' in P. Newman (ed) The New Palgrave Dictionary of Economics and the Law, (1998) 442, 447.

116 M. Olson, The Logic of Collective Action (Cambridge: Harvard Univ Press, 1965) pp 1-3

117 The Law Society, Memorandum by the Society's Standing Committee on Company Law: A New Form of Incorporation for Small Firms (The Law Society, No 79, 1981); Forum of Private Business, A Report into Business Legal Structures (London: 1991), Company Law Review: The Law Applicable to Private Companies (London: DTI, URN 94/529, 1994).

118 B. Cheffin, 'Trust, Loyalty and Cooperation in the Business Community: Is Regulation Required?'in B. Rider (ed) et al, The Realm of Company Law (Oxford: Clarendon Press) p 53, 79.

119 O.E. Williamson, The Economic Institutions of Capitalism (New York, 1985) p 391.

120 M.J. Whincop, 'Overcoming Corporate Law: Instrumentalism, Pragmatism and the Separate Legal Entity Concept', (1997) 15 Comp \& Sec LJ 411, 412. 
324 Northern Ireland Legal Quarterly [Vol. 51, No. 2]

also add up to the unconscious attainment of a greater good for all." ${ }^{121}$

121 B. Chapman, 'Trust, Economic Rationality, and the Corporate Fiduciary Obligation’, (1993) 43Univ Toronto LJ 547, 588. 